\title{
Female Rebellion in the Margins of a Late Thirteenth-Century Mort de Roi Artu
}

\author{
Emily Shartrand \\ University of Delaware (Department of Art History), \\ United States of America, eshartra@udel.edu
}

\section{Abstract}

In the margins of a late thirteenth century Franco-Flemish copy of the Arthurian Vulgate cycle, New Haven, Beinecke Rare Books $\mathcal{E}$ Manuscripts Library, Ms. 229, a woman picks up her distaff, not to spin thread, but rather to mount a horse and joust against a defenseless man. In this instance, the motif's interaction with the component parts of the manuscript page is crucial for understanding its meaning. This paper will discuss the implications of a marginal motif depicting a physical battle between a mounted woman and man which appears in manuscript owned by a family of Flemish nobility in open rebellion against the French crown.

Keywords: Arthurian romance; marginal art; distaff; joust; rebellion; Dampierre; medieval manuscript. 


\title{
Female Rebellion in the Margins of a Late Thirteenth-Century Mort de Roi Artu
}

\author{
Emily Shartrand \\ University of Delaware, United States of America
}

\section{Introduction}

When a woman picks up her distaff to mount a horse and use it to joust with a defenseless man, what is the significance? Just such a motif appears in the margins of a late thirteenth-century Franco-Flemish copy of the Arthurian Vulgate cycle, New Haven, Beinecke Rare Books \& Manuscripts Library, Ms. 229. ${ }^{1}$ In fact, the appropriation of objects traditionally associated with women's work which then become instruments of warfare are common throughout several editions of this cycle. One of the most provocative instances of this marginal motif occurs on folio 329r (Fig. 1-3).

This page opens on the final chapter of the Arthurian Vulgate cycle, La Mort de Roi Artu, as the story reaches a climactic moment. Mordret, in an act of betrayal, pens a false announcement to King Arthur's barons that the king has died and left him in control. The letter, which has been given legitimacy through the affixed seal of the king, goes on to request that Queen Genieure now become Mordret's wife. ${ }^{2}$ Genieure alone is suspicious of the letter; at first, she delays a response but then eventually she refuses Mordret's suit. ${ }^{3}$ La Mort de Roi Artu is the least repetitive book of the Vulgate Arthur and the one that reads the most

\footnotetext{
${ }^{1}$ For catalogue entry, bibliographic references, and exhibition history please see Alison Stones, Gothic Manuscripts 1260-1320 (London: Harvey Miller Publishers, 2013), Part I, Volume II, 550-575.

2 The spelling of names reflects that used in Ms. 229.

${ }^{3}$ Lancelot-Grail. The Old French Arthurian V ulgate and Post-V ulgate in Translation, ed. Norris J. Lacy (New York: Garland Publishing, Inc., 1995), Volume IV.
} 
like a chronicle. It outlines how Lancelot and Queen Genieure's affair ignites a vendetta between the families of King Arthur and Lancelot.

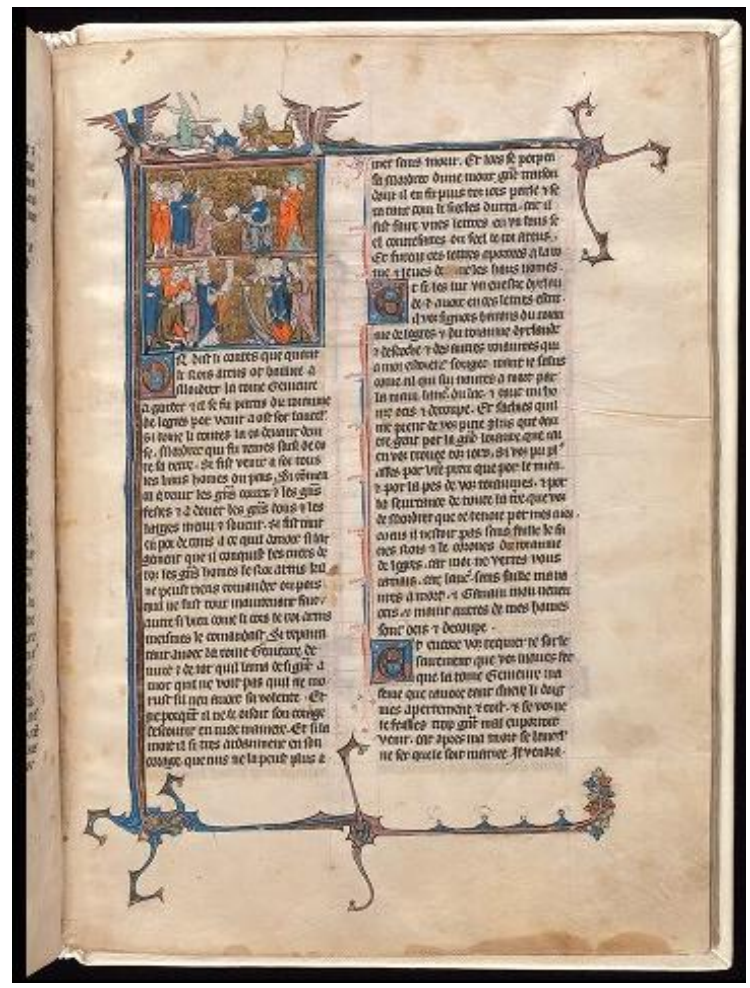

Fig. 1. New Haven, Beinecke Rare Books and Manuscripts Library, Yale University, Ms. 229, fol. 329r.

The battles that ensue leave King Arthur's rule weak and allows Mordret to enact his treasonous plot. The tale culminates in a battle on Salisbury Plain where King Arthur and Mordret kill one another. ${ }^{4}$ Beinecke, Ms. 229 is an intriguing case study for La Mort de Roi Artu and the rest of the Arthurian Vulgate cycle because rarely have Arthurian Romances been decorated with such extensive programs of

${ }^{4}$ E. Jane Burns, "Introduction," in Lancelot-Grail. The Old French Arthurian Vulgate and Post-Vulgate in Translation, ed. Norris J. Lacy (New York: Garland Publishing, Inc., 1995), Volume I, XXXI. 
marginal art. ${ }^{5}$ In the conclusion to her article "The Study of Marginal Imagery: Past, Present, and Future", Lucy Freeman Sandler encouraged scholars of marginal motifs to consider both "every aspect of their meaning, including contradictory and overlapping meanings," and, "the page and the book as a whole from the point of view of its physical making." " 6 The multivalent nature of both the Arthurian tales and marginal motifs allows for new conclusions to be drawn when the two appear to operate together, as is the case with folio 329r.

Accompanying the text is a miniature on the top-left of the folio, comprised of two registers (Fig. 2). The top register depicts the arrival of the false letter at court as Mordret's paid messenger hands the letter with King Arthur's seal to a seated Genieure in the presence of the barons of Logres (modern day Britain). The bottom register mirrors the symmetry of the top, and depicts a bishop reading of the contents of the letter. While the top register is calm in tone, the bottom evokes extreme distress. Genieure's eyes are wide with shock as her hands pull at her collar. Her two ladies turn towards each other as one grasps the other's arm for support. Their skirts sweep to the right in dramatic diagonals. On the opposite side of the image, the barons gesticulate even more wildly and Mordret faints in mock distress. A careful study of this miniature reveals a final important element. In the top register, one of the barons present at the letter's arrival points upward to a jousting man and woman in the margin, forging a connection between the text, miniature, and marginalia. Despite the manuscript's abundant decoration, this is one of the few instances where a visual connection is made between miniature and margin so overtly. The inclusion of the pointing baron forces the viewer to investigate how the marginal jousting man and woman affects the interpretation of this moment within La Mort de Roi Artu

\footnotetext{
5 To see a complete list of Arthurian Romance manuscripts with their contents, date and location of production, quantity of illustrations, with links to their current housing libraries please see Alison Stones, The Lancelot-Grail Project: Chronological and Geographic Distribution of Lancelot-Grail Manuscripts, revised 2016. http://www.lancelotproject.pitt.edu/LG-web/Arthur-LG-ChronGeog.html.

${ }^{6}$ Lucy Freeman Sandler, "The Study of Marginal Imagery: Past, Present, and Future," in Studies in Manuscript Illumination (London: The Pindar Press, 2008), 76-126.
} 


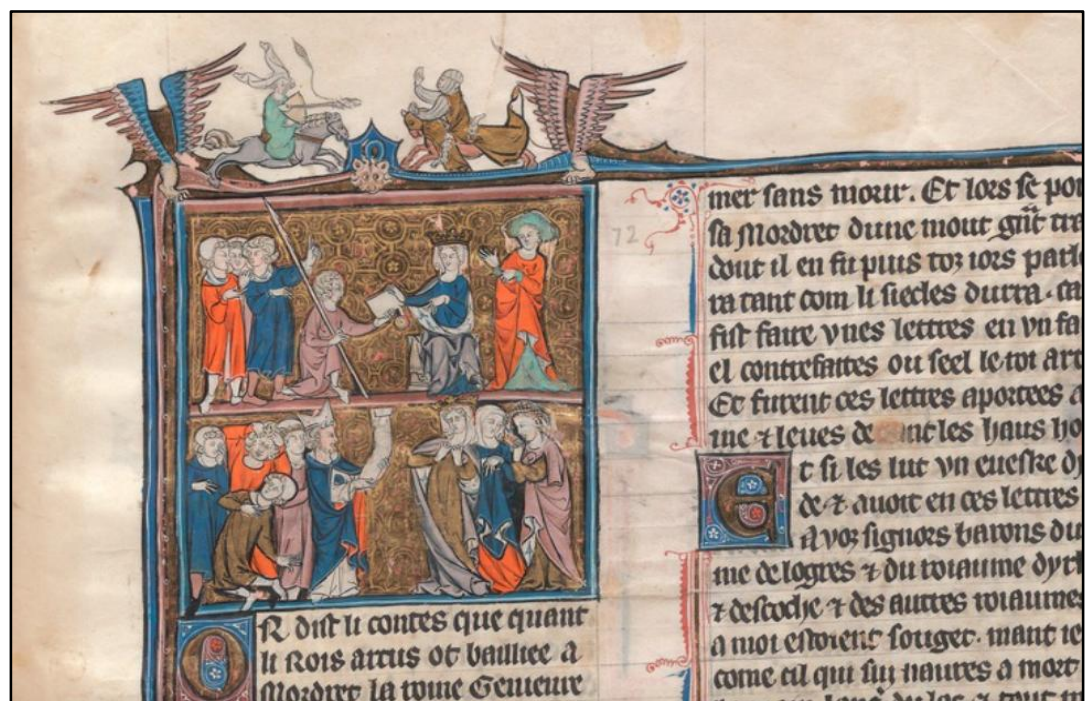

Fig. 2. New Haven, Beinecke Rare Books and Manuscripts Library, Yale University, Ms. 229, fol. 329r, detail

\section{Context of the miniature and marginal illustration}

Beinecke, Ms. 229 is the final part of what once was a multiple volume set of the Arthurian Vulgate cycle, illuminated sometime between 12701295 CE. The other extant volume, Paris, Bibiothèque Nationale de France, Français 95, is identical in terms of codicology and the layout of the folios. ${ }^{7}$ Both are in a large format and illuminated in their entirety by the same pair of artists; they also contain an extensive miniature cycle as well as marginal images on many of the pages. Several chapters of the Vulgate Cycle of Arthurian romances have traditionally been read as a commentary on the negative effects of rebellion against central authority. R. Howard Bloch has argued that the final chapter of the cycle (La Mort de Roi Artu) demonstrates the failings of a divided feudal system as France moved towards an era of increased power in a

${ }^{7}$ For catalogue entry, bibliographic references, and exhibition history please see Alison Stones, Gothic Manuscripts 1260-1320 (London: Harvey Miller Publishers, 2013), Part I, Volume II, 550-575. 
centralized government. ${ }^{8}$ Beinecke, Ms. 229 and BnF fr. 95 were most likely produced for the Flemish Count Guy of Dampierre or a member of his family some decades before his victory against the French king in the Battle of the Golden Spurs at Courtrai in 1302. In this context, rebellion might appear as a necessary response to a failing political system and this same chapter of the Vulgate cycle a text that questioned the ability of one king to rule over divided lands after all. ${ }^{9}$ The inclusion of rebellious women in the margins of these manuscripts may in fact provide clues as to how Count Guy and his family would have reinterpreted the tale of La Mort de Roi Artu based on their own political leanings. While Bloch's interpretation of La Mort de Roi Artu holds true in other contexts, this article seeks to employ a close analysis of the relationship between the text, miniature, and marginalia on folio 329r in order to affirm that different interpretations are necessary in the case of the Dampierre family's manuscript.

The motif depicted in the margin on folio 329r of Beinecke, Ms. 229 appears directly above the miniature between a frame composed of two griffins erupting from the borders (Fig. 3). It is one of the three malefemale jousting couples in the two volumes. All three jousting couples are comprised of the same basic elements. The male and female figures are mounted on horseback and charging one another with the woman always on the left. ${ }^{10}$ In two out of the three marginal images (folio 226r of BnF fr. 95 and folio 329r of Beinecke, Ms. 229), the woman is armed with a distaff and the knight she battles is weaponless. In the third (folio 100v of Beinecke, Ms. 229) both the woman and man have lances though the man (who is tonsured and clearly meant to represent a monk) has a lance which is comically broken in half. ${ }^{11}$ The couple on folio $329 \mathrm{r}$ is of the first type.

\footnotetext{
${ }^{8}$ R. Howard Bloch, "The Death of King Arthur and the Waning of the Feudal Age," Orbis Litterarum XXIX (1974): 291-305.

${ }^{9}$ Lynn T. Ramey, "Images of Rebellion: The Social and Political Context of the Images of Yale 229 La Mort le Roi Artus," in Essays on the Lancelot of Yale 229, ed. by Elizabeth M. Willingham (Turnhout: Brepols, 2007), 9.

10 Paris, Bibliothèque Nationale de France, Français 95, fol. 226r, bottom margin; http://gallica.bnf.fr/ark:/12148/btv1b6000108b/f459.image.

11 Beinecke Rare Books \& Manuscripts Library, Yale University, Ms. 229, fol. 100v, bottom margin; https://brbl-zoom.library.yale.edu/viewer/1020129.
} 


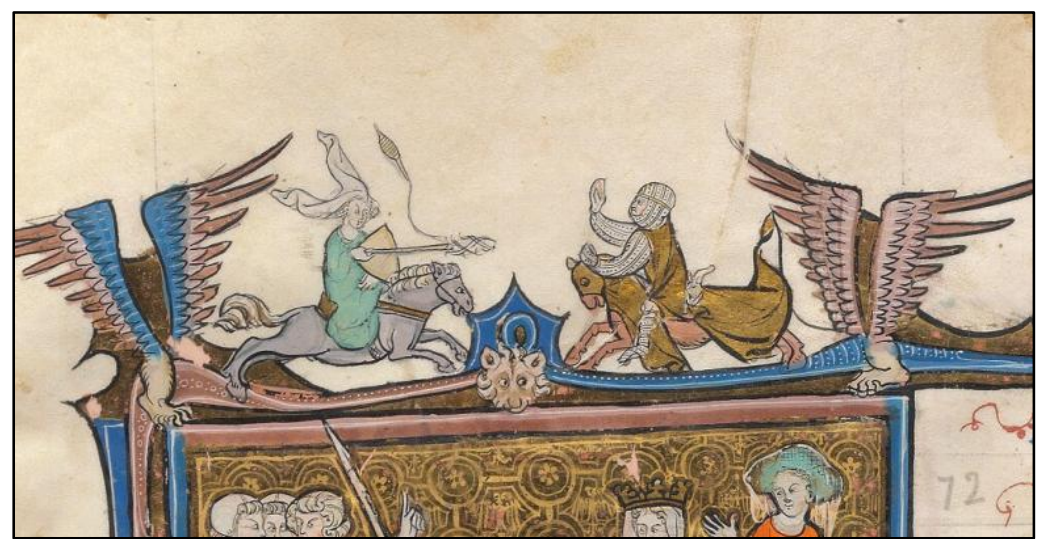

Fig. 3. New Haven Beinecke Rare Books and Manuscripts Library, Yale University, Ms. 229, fol. 329r, detail

The woman wields a distaff with its spindle flying up into the air. Her other hand holds a shield and her hair is contained in a hairnet and wrapped in a knotted hennin that, like the spindle, flaps in the breeze. Her male jousting partner is obviously at a disadvantage. Dressed as a knight with a chain mail hauberk, he carries no weapon or shield and consequently raises his hands up in an attempt to block the impending attack.

The male-female distaff joust is moreover part of a much larger marginal group that can be identified throughout both volumes. Another essay by Lucy Freeman Sandler entitled"A Series of Marginal Illustrations in the Rutland Psalter" provides a framework for studying such connections in seemingly disparate marginal illustrations. ${ }^{12}$ Of the Rutland Psalter, she states: "Certain of the apparently isolated illustrations of the manuscript are actually held together by a chain of relationships in which a number of motifs are manipulated in a complex and shifting manner". ${ }^{13}$ In this way the various manipulations of a marginal motif throughout a manuscript's decorative program create an expansion process. Essentially, one motif can form the basis

12 Lucy Freeman Sandler, "Marginal Illustrations in the Rutland Psalter," in Studies in Manuscript Illumination (London: The Pindar Press, 2008), 1-32.

13 Sandler, "Marginal Illustrations in the Rutland Psalter," 2. 
for another series of marginal illustrations. ${ }^{14}$ By breaking down the male-female distaff joust into its component elements and identifying those elements in other marginal illustrations, it becomes clear that this marginal group makes up the majority of the images appearing in the borders of Beinecke, Ms. 229 and its sister manuscript, BnF fr. 95.

Some of these elements are as follows: male-female interactions, women holding distaffs or spindles, knights jousting and fighting, and men being penetrated (or in the process of it) by some form of a weapon. The borders are rife with these violent and, in many ways, sexual images. ${ }^{15}$ The seemingly calm depictions of women spinning become potentially suggestive when seen alongside women jousting against men with similar objects. An image depicting a traditional courtly couple, for instance, a woman holding a wreath out to a seated scholar (see footnote for a link to the digitized folio), can be interpreted differently when compared to depictions of Phyllis riding Aristotle (again, see footnote). ${ }^{16}$ Since both have similar physical attributes, it suggests that they are two scenes from the same story (i.e. that the courtly couple is in fact a depiction of Phyllis seducing Aristotle), making these motifs the earliest extant depiction of the mounted Aristotle tale in art. ${ }^{17}$ Finally, a charming scene depicting a knight struggling to reload a crossbow becomes practically phallic when the margins are rife with men being penetrated by similar weapons. ${ }^{18} \mathrm{By}$

\footnotetext{
14 Ibidem, 11.

15 If you wish to investigate these marginal images further it is possible to access complete digital copies of Beinecke, Ms. 229 and BnF fr. 95 at the following web addresses respectively: https://brbl-dl.library.yale.edu/vufind/Record/3433279 and http://gallica.bnf.fr/ark:/12148/btv1b6000108b.

16 Paris, Bibliotheque Nationale de France, Français 95, fol. 254r, bottom margin; http://gallica.bnf.fr/ark:/12148/btv1b6000108b/f515.image and Paris, Bibliothèque Nationale de France, Français 95, fol. 61v, bottom margin; http://gallica.bnf.fr/ark:/12148/btv1b6000108b/f130.image.

17 Susan L. Smith, The Power of Women (Philadelphia: University of Pennsylvania Press, 1995), 112.

18 Madeline Caviness found a nearly identical image of a knight reloading his crossbow in the margins of the Hours of Jeanne d'Evreux to be phallic as well, in the context of the numerous other sexually suggestive marginal illustrations found in that manuscript. Madeline Caviness, "Patron or Matron? A Capetian Bride and a Vade Mecum for Her Marriage Bed” Speculum 68, no. 2 (1993): 333-362. Bibliothèque Nationale de France, Français 95 , fol. 203v, bottom margin; http://gallica.bnf.fr/ark:/12148/btv1b6000108b/f414.image.
} 
viewing all of these individual motifs as part of a larger marginal group, they become imbued with significance beyond that of "genera scene" or "comic relief". Together, they can be understood as a reversal of traditional male-female sexual roles; in these male-female jousts, the distaff as a phallus becomes the means of penetration.

In Ruth Mazo Karras's Sexuality in Medieval Europe, she explains that sex in the medieval period it was understood as an action done to another person, not a mutual act like it is understood today. In fact, the French verb foutre, which is commonly used to describe the act of sex, has an older translation, which means to penetrate. The definition of "natural" or "normative" sex is complex and difficult to define in the medieval period but Karras argues that gender inversion where men played the passive role in sexual interactions constituted an abnormal sexual preference. ${ }^{19}$ In a society where sex was viewed as an act in which one person (traditionally male) does something to another person (traditionally female) the reversal of role with respect to penetration is striking and likely significant.

\section{Women textile workers and lyric poetry}

Furthermore, the distaff as an object contained socio-economic implications. The thirteenth century saw the growth of bourgeois urban centers in Flanders such as Bruges and Ypres that produced large quantities of textiles. ${ }^{20}$ Between 1270 and 1281 - around the time that Beinecke, Ms. 229 and $\mathrm{BnF}$ fr. 95 were produced - there were a number of uprisings of cloth workers against the local urban elite as well as in response to unpopular textile trade deals made by Count Guy of Dampierre and his mother Countess Margaret II. ${ }^{21}$ There is also evidence that women were significantly represented in the cloth trade and that their positions were subject to some level of protection. ${ }^{22}$ It is arguable that the professions of weaving, spinning, and draping became

\footnotetext{
${ }^{19}$ Ruth Mazo Karras, Sexuality in Medieval Europe: Doing Unto Others (Philadelphia: Taylor \& Francis, 2012), 3.

20 David Nicholas, Medieval Flanders (New York: Longman, 1992), 182-4.

${ }^{21}$ Nicholas, Medieval Flanders, 176-84.

${ }^{22}$ For example, there was a law in Ypres that if a man from one part of the cloth trade, eg. a draper, married a woman from another part, eg. a weaver, then each party was allowed to keep their individual professions. David Nicholas, Medieval Flanders (New York: Longman, 1992), 183.
} 
synonymous with rebellion in late thirteenth-century Flanders and that women in particular had an economic stake in the success of these uprisings.

Spinning, in addition to being an accepted form of women's work and the distaff an object of economic power, was also a tool for female agency. Precedent for courtly women deriving personal power from the act of spinning or sewing can be found within a subgenre of Old French lyric poetry, the chansons de toile. These songs, all with female voices, tell stories of often forcibly enclosed women who lament their absent lovers. ${ }^{23}$ Chansons de toile were embedded within longer romance epics in the late twelfth and thirteenth centuries, most notably Jean Renart's Guillaume de Dole which contains six. ${ }^{24}$ The spinning women of Beinecke, Ms. 229 and $\mathrm{BnF}$ fr. 95 resemble the near contemporary world of Guillaume de Dole more so than the mythical past seen in the Arthurian Vulgate. Renart even described his hybrid text with inserted lyrics, a composition that could be compared to the expertly integrated diversity of manuscript margins, using textile imagery. ${ }^{25}$ The chansons he included appear to have arisen as an accompaniment to women's needlework. ${ }^{26}$ The difference between these songs and other lyric poems with a female voice such as those of the trowvere is twofold. First, in the chansons de toile the women pair their passive lament with the active work of weaving, sewing, or embroidering. Second, they conclude with the women being reunited with their lovers.

E. Jane Burns in Courtly Love Undressed, argues, "If trouvere lament often records unfulfilled and prolonged male desire, the women who sew in the chanson de toile sing of love that works, like needles through

${ }^{23}$ E. Jane Burns, Courtly Love Undressed: Reading Through Clothes in French Medieval Culture (Philadelphia: University of Pennsylvania Press, 2002), 96.

24 McCann Boulton and Moureen Barry, "Lyric Insertions and the Reversal of Romance Conventions in Jean Renart's Roman de la Rose or Guillaume de Dole," in Jean Renart and the Art of Romance: Essays on Guillaume de Dole, ed. Nancy Vine Durling, (Gainsville, Fl: University Press of Florida, 1997), 85.

25 “car aussi com l'en met la graine/ es dras por avoir los et pris/ einsi a il chans et sons mis/ en cestui Romans de la Rose/ qui est une novele chose." Nancy A. Jones, "The Uses of Embroidery in Jean Renart: Gender, History, Textuality," in Jean Renart and the Art of Romance: Essays on Guillaume de Dole, ed. Nancy Vine Durling (Gainsville, Fl: University Press of Florida, 1997), 13-14.

26 Songs of the Troubadours and the Trovères; And Anthology of Poems and Melodies, eds. Samuel Rosenberg, Margaret Switten, and Gérard Le Vot (New York: Garland Publishing, 1998), 184. 
cloth, pulling desirous partners into mutual embrace."27 For example, in one chanson the Beautiful Yolande sews with her mother and slowly asserts her desire to take a lover, eventually changing her mother's mind on the matter. ${ }^{28}$ In another similar chanson, the heroine sews a robe of silk for her lover who then appears before her and they embrace. ${ }^{29}$ Not all of the chansons have happy endings, however. In a third, the Lovely Doette does not sew but instead reads, and thinks about her love who has gone to tourney far away. Later, when she discovers that he has died, the Lovely Doette sets aside her fur-lined cloak and instead builds an abbey as a refuge for all those that know the grief of love. ${ }^{30}$

Burns argues that the chansons de toile demonstrate a tension between women as objects of desire and their participation in physical work. ${ }^{31}$ This tension suggests that traditionally women could only take on a single role, that of a beautiful object or an active worker. By creating a character that is both things at once, the balance has been upset. Additionally, sewing may not be coded as a quintessentially male behavior, but singing a love song was. The women of the chansons de toile have taken control of this activity and have done so by being active workers..$^{32}$ In a parallel manner, marginal images of women spinning in manuscripts engage in this tension between active and passive. They also represent women as objects of desire who are sometimes

\footnotetext{
27 "Bele Yolanz en chamber koie/sor ses genouz pailes desploie/Cost un fil d'or, l'autre de soie/Sa male mere la chastoie." Michel Zink, Essai sur les chansons de toile (Ontario: Champion, 1978), 96. Discussed in Burns, Courtly Love Undressed, 105. Burn's book acts as a useful model for this discussion because it reassesses courtly love through the lens of garments typical of court life that are described in literary accounts,

${ }_{28}$ Burns, Courtly Love Undressed, 100.

29 "Bele Yolanz en ses chambres seoit/D'un boen samiz une robe cosoit/a son ami tramettre la voloit/...Li siens amis entre ses braz la prent/en un biau lit s'asient seulement/Bele Yolanz lo baise estroitement/a tor François enmi lo lit l'estent." Zink, Essai sur les chansons de toile, 77-78.

30 "Bele Doette as fenestres se siet/Lit en un livre mais au cuer ne l'en tient/De son ami Doon li resovient/...Por vostre amor vestirai je la haire/ $\mathrm{Ne}$ sor mon cors n'avra pelice vaire/...Bele Doette prist s'abaiie a faire." Songs of the Troubadours and the Troveres; And Anthology of Poems and Melodies, eds. Samuel Rosenberg, Margaret Switten, and Gérard Le Vot (New York: Garland Publishing, 1998), 187.

31 Burns, Courtly Love Undressed, 93-95.

32 Burns, Courtly Love Undressed, 93-95.
} 
simultaneously engaged in active work. ${ }^{33}$ Perhaps, therefore, the use of a distaff by the jousting women as their tool of penetration implied that rising power and autonomy in economic and social spheres was seen as encouraging women to rebel against their prescribed gender role.

While the male-female distaff joust that appears on folio 329r of Beinecke, Ms. 229 does not directly relate to or illustrate the text of $\mathrm{La}$ Mort de Roi Artu, its presence on the page aids the modern readerviewer in understanding how Count Guy and his family may have interpreted the Arthurian tale differently based on their current political situation. Folio 329r depicts several different forms of rebellion simultaneously. As part of the tale of La Mort de Roi Artu, it alludes to the larger rebellion of this text, that of Lancelot against Arthur and Gauain in response to Lancelot's relationship with Genieure and his killing of Gauain's brothers in an effort to save her from punishment and death. In the text and miniature of the folio itself, two additional rebellions take place. Mordret has rebelled against Arthur in order to take control of the barons of Longres and Genieure is plotting a rebellion against Mordret by refusing to become his wife. Finally, the jousting woman and man in the margins mirror's Genieure's rebellion against Mordret, yet in this instance the battle of wills has become a physical attack, one that the woman is poised to win.

\section{Interpreting images of female rebellion}

As stated previously, La Mort de Roi Artu has traditionally been read as a commentary on the failings of a divided feudal government. As outlined by Bloch in his essay "The Death of King Arthur and the Waning of the Feudal Age", La Mort de Roi Artu depicts a king unable to choose between state-right and kin-right, between public and private loyalties. When Arthur's private feelings affect the outcome of Genieure's trial for adultery, it ultimately results in the death of Gauain's brothers and turns what was once a family feud into a civil conflict. ${ }^{34}$ It is Lancelot, a Frenchman with an ability to set aside old scores, who embodies the growth of Capetian centralized power and the newly popular Aristotelian view of sacrificing self-interest for the

\footnotetext{
33 Paris, Bibliothèque Nationale de France, Français 94, fol. 141r, bottom margin; http://gallica.bnf.fr/ark:/12148/btv1b6000108b/f289.image.

${ }^{34}$ Bloch, "The Death of King Arthur and the Waning of the Feudal Age," 299.
} 
common social good. ${ }^{35}$ Mordret, conversely, is an emblem of the old world order. As the political link between the barons and Arthur, he is able to operate within the established feudal system and manipulate and bribe his vassals for personal gain ${ }^{36}$ Mordret may be the villain of the story, but he is merely exploiting the failing political structure that Arthur kept in place.

This reading of the text demonstrates how Arthur hastens his own demise by clinging to a political system that was no longer viable, yet Count Guy of Dampierre and his family likely would have interpreted certain aspects of the story differently. Beinecke, Ms. 229 and BnF fr. 95 are both large in size and their illumination extensive and high in quality, making them likely display pieces and objects of communal reading and viewing. Unlike many smaller format manuscripts that can be connected to a single original owner, several generations the Flemish counts and countesses would likely have had access to these books from the outset, both men and women. While this does allow for a multiplicity of interpretations within the family, there are some interpretations that seem more likely given the contemporary political climate. Between 1285 and 1314, Count Guy and his son Robert III of Flanders were in almost constant conflict with Philip IV 'the Fair' of France. Philip often worked with lesser nobility and urban leaders in the Low Countries to circumvent the control of Count Guy who, like Mordret, was the link between the French state and the rest of Flanders. ${ }^{37}$ There are two ways that the nobles of Flanders could have reinterpreted the text in a way that complicates R. Howard Bloch's reading the tale. First, Count Guy and his family, resentful of the King's attempts to upset their rule, may have looked upon Mordret's actions more favorably than other late thirteenth-century readers of the Arthurian Vulgate Cycle. Second, the Dampierres could have still seen Mordret as a negative character, but instead inverted Bloch's interpretation of Lancelot from a figure representing the growth of

\footnotetext{
35 Bloch's assertion here is based on re-readings of Aristotle that influenced Thomas Aquinas's Summa Theologica and the concept of "iustitia particularis" vs "iustitia generalis" and the idea of man's responsibility to his state. Bloch, "The Death of King Arthur and the Waning of the Feudal Age," 302.

36 Bloch, "The Death of King Arthur and the Waning of the Feudal Age," 295.

${ }^{37}$ Nicholas, Medieval Flanders, 186-7.
} 
Capetian power to that of a virtuous rebel, as they likely saw themselves.

These inverted readings of La Mort de Roi Artu are strengthened through an analysis of female rebellion on folio 329r. To begin, the distaff wielding woman is meant to be ridiculous, both to the modern and medieval eye. Her flapping hennin and flying spindle appear comic when juxtaposed with her upright posture and sidesaddle seat. Her cocked brows and smirking lips become sinister when one realizes her distaff is about to penetrate the defenseless knight. The viewer is meant to have sympathy for this knight's plight. His brow is furrowed in real concern as he realizes the utter uselessness of his upraised hands. The lady's actions seem unnecessarily cruel, which sheds a negative light on her act of rebellion. Her choice of a distaff as weapon drives home her status as a woman and a galling disregard for womanhood's prescribed behaviors. Any character from La Mort de Roi Artu that a contemporary reader would associate with this woman, whether based on gender or placement within folio 329r, would then take on similarly negative connotations.

For example, if Mordret represents the political position of Count Guy and his family by operating within the established system, then Genieure is ignoring feudal structure completely. She has been placed under the protection of Mordret and is therefore subject to him. As she does not yet know that the letter from a dying Arthur commanding her to marry Mordret is false, she has no grounds for her rebellion. Genieure's story continues on subsequent folios where she shuts herself into a tower and forces Mordret and the barons of Longres to lay siege. ${ }^{38}$ Although she does not take up arms herself, Genieure is still subverting the role she was supposed to play within the political system. Her actions can be seen as synonymous to those of the lesser nobility in Flanders who attempted to work with Philip the Fair against the interests of Count Guy and his family. ${ }^{39}$ When the baron in the top-left register of the miniature points upward to the distaff-wielding lady in the margin, he is encouraging the reader to draw a parallel between this woman and another figure from the miniature, in this case Genieure. This explicitly unfavorable reading of the lady's actions strengthens the

38 Lancelot-Grail. The Old French Arthurian Vulgate and Post-Vulgate in Translation, ed. Norris J. Lacy, Volume IV.

${ }^{39}$ Nicholas, Medieval Flanders, 187. 
implicit understanding of Genieure's rebellion as inappropriate as well. Given the context of Beinecke, Ms. 229, the male-female distaff joust motif acts as a moralizing gesture against Genieure's actions, guiding the reader to an interpretation of the story that is more in line with the Dampierre family's current political sensibilities.

In contrast, this same marginal woman could have been visually associated with the character of Mordret instead of Genieure. Despite the Dampierre family's likely sympathy for the established feudal system, it is also arguable that Mordret is too much the villain for some readers to applaud. Moreover, the jousting woman appears directly above Mordret's character in the accompanying miniature. On folio $329 \mathrm{r}$ both the miniature and corresponding marginal motif are highly symmetrical. Mordret and the men of court are on the left side of both registers where as Genieure and her ladies are on the right. Perhaps surprisingly, the distaff-wielding woman is not found on the right side of the upper margin. She is instead on the left, above Mordret, whereas the defenseless knight corresponds symmetrically with Genieure. It is, in fact, the woman who holds the weapon poised for penetration and the knight who is given nothing to stop the attack other than his hands. This reversal of gender roles in the case of the jousting man and woman suggests that the woman's actions affect the interpretation of Mordret's.

Within the story of La Mort de Roi Artu, Mordret and Genieure's conflict mirrors that of King Arthur and Lancelot. If the Dampierre family read the figure of Lancelot not as the embodiment of Capetian centralized power but instead as a virtuous rebel fighting against the authority of King Arthur, they may too have read Genieure's response to the false letter as a similarly virtuous rebellion against Mordret. In both cases, the characters of Lancelot and Genieure have started conflicts with those who had political authority over them, just as Count Guy and Flanders were subject to Philip 'the Fair's' control. By forging a visual connection between Mordret and the jousting woman, the artists allowed a reading of the image (and thus the text) in which Mordret's actions are equated to those of a woman who has cast aside her own virtue in order to take on the male role of a mounted jouster and imminent penetrator. This possible association emphasizes a negative reading of Mordret, not Genieure, for the Dampierre family. 


\section{Conclusions}

These two divergent interpretations of folio 329r outline how difficult it can be to parse out the significance of a marginal motif and how it might be used to better understand a manuscript page. Through this analysis of the male-female distaff joust on folio 329r of Beinecke, Ms. 229, two divergent interpretations of Mordret and Genieure have been argued. Both readings, while contradictory, suggest a new way of understanding La Mort de Roi Artu by creating positive associations with the power structure of the feudal system and rebellion against central authority. Furthermore, these new interpretations demonstrate how even within a context where political rebellion is lauded, an image of non-royal female rebellion against prescribed gender roles is still used to create negative associations.

\section{References}

\section{Primary Sources}

New Haven, Beinecke Rare Books \& Manuscripts Library, Ms. 229.

Paris, Bibliothèque Nationale de France, Français 95.

\section{Secondary Sources}

Bloch, R. Howard. "The Death of King Arthur and the Waning of the Feudal Age." Orbis Litterarum XXIX (1974): 291-305.

Boulton, McCann, and Moureen Barry. "Lyric Insertions and the Reversal of Romance Conventions in Jean Renart's Roman de la Rose or Guillaume de Dole." In Jean Renart and the Art of Romance: Essays on Guillaume de Dole. Ed. Nancy Vine Durling, 85-104. Gainsville: University Press of Florida, 1997.

Burns, E. Jane. Courtly Love Undressed: Reading Through Clothes in French Medieval Culture. Philadelphia: University of Pennsylvania Press, 2002.

Caviness, Madeline. "Patron or Matron? A Capetian Bride and a Vade Mecum for Her Marriage Bed." Speculum 68, no. 2 (1993): 333-362. Jones, Nancy A. "The Uses of Embroidery in Jean Renart: Gender, History, Textuality." In Jean Renart and the Art of Romance: Essays on 
Guillaume de Dole. Ed. Nancy Vine Durling, 3-44. Gainsville:

University Press of Florida, 1997.

Lacy, Norris J., ed. Lancelot-Grail. The Old French Arthurian Vulgate and

Post-V ulgate in Translation. New York: Garland Publishing, 1995.

Volumes I-IV.

Mazo Karras, Ruth. Sexuality in Medieval Europe: Doing Unto Others.

Philadelphia: Taylor \& Francis, 2012.

Nicholas, David. Medieval Flanders. New York: Longman, 1992.

Ramey, Lynn T. "Images of Rebellion: The Social and Political Context of the Images of Yale 229 La Mort le Roi Artus." In Essays on the Lancelot of Yale 229. Ed. Elizabeth M. Willingham, 7-14. Turnhout: Brepols, 2007.

Rosenberg, Samuel, Margaret Switten, and Gérard Le Vot, eds. Songs of the Troubadours and the Troveres; An Anthology of Poems and Melodies. New York: Garland Publishing, 1998.

Sandler, Lucy Freeman. "Marginal Illustrations in the Rutland Psalter." In Studies in Manuscript Illumination, 1-32. London: The Pindar Press, 2008.

. "The Study of Marginal Imagery: Past, Present, and Future." In Studies in Manuscript Illumination, 76-126. London: The Pindar Press, 2008.

Stones, Alison. Gothic Manuscripts 1260-1320. London: Harvey Miller Publishers, 2013. Part I, Volume II. . The Lancelot-Grail Project: Chronological and Geographic Distribution of Lancelot-Grail Manuscripts, revised 2016. Accessed May 29th 2018. http://www.lancelot-project.pitt.edu/LG-web/Arthur-LGChronGeog.html.

Smith, Susan L. The Power of Women. Philadelphia: University of Pennsylvania Press, 1995.

Zink, Michel. Essai sur les chansons de toile. Ontario: Champion, 1978 